\title{
Determinants of Demand for Automobiles in Brazil: An Econometric Analysis in the Period 2012-2017
}

\author{
Pedro Raffy Vartanian ${ }^{1} \&$ Paulo Henrique Silva de Oliveira ${ }^{2}$ \\ ${ }^{1}$ Adjunct Professor of Economics, Mackenzie Presbyterian University, São Paulo, Brazil \\ ${ }^{2}$ Master in Economics Candidate, Mackenzie Presbyterian University, São Paulo, Brazil \\ Correspondence: Pedro Raffy Vartanian, Master in Economics and Markets - Mackenzie Presbyterian University, \\ Rua Itambé, 135 (building 12), 01302-907, São Paulo, Brazil. Tel: 55-11-2766-7411. E-mail: \\ pedro.vartanian@mackenzie.br
}

Received: April 24, 2020

Accepted: May 31, 2020

Online Published: June 5, 2020

doi:10.5539/ijef.v12n7p1

URL: https://doi.org/10.5539/ijef.v12n7p1

\begin{abstract}
This paper aims to investigate the determinants of demand for automobiles in Brazil in the period 2012-2017. To this end, the research initially contemplates a historical approach that shows that the sector developed, at first, guided by the State and, subsequently, in a race by foreign automakers to build the respective production plants, until it became one of the main sectors of the Brazilian economy, whose performance directly reflects the behavior of all national production. The second step was to model the contemporary behavior of the sector, where it can be seen that some variables, such as income, price, interest rate, IPI rates, and seasonality, have relevant statistical significance and can be used to interpret demand and make forecasts about the future of the sector. An econometric estimate based on ordinary least squares with a dummy variable was used. Among the results found, the importance of the income and price effects as important determinants of demand for automobiles in Brazil in the analyzed period stands out.
\end{abstract}

Keywords: demand, automobiles, econometric model

\section{Introduction}

This work aims to investigate the main determinants in the demand for automobiles from 1000 to 2000 cylinders in Brazil through an economic model calculated by the ordinary least square. In this sense, it is understood that in addition to the economic methodology employed, it is also necessary to wander the past and include what types of economic and industrial policies conducted by both the State and the private sector that contribute to the interpretation of the sector.

Justification for seeking answers on what are the main determining factors in the demand for automobiles from 1000 to 2000 cylinders in Brazil between 2012 and 2017, society as a whole is intimately registered in the questions: Knowledge of an economic model that helps to understand the determinants of demand for automobiles is essential for the automakers to plan their production and investment levels, in a way that can increase the efficiency of their scarce economic resources.

The automobile sector shows a fundamental role within the production levels of an economy, as its activities have a high-income multiplier effect, either downstream or in value. According to ANFAVEA (2018), an automotive production chain is responsible for $22 \%$ of Industrial Production and $4 \%$ of the Brazilian Total Gross Domestic Product. The institution also claims that the sector employs, directly and indirectly, 1.6 million people.

Thus, knowledge of the determinants of demand for automobiles, in addition to the direct effect on automakers, is fundamental for the entire production chain that carries out its chemical planning, such as parts and input suppliers, logistics agents, distributors and retailers, maintenance and repair, insurance companies, credit institutions, informal economy, and micro-entrepreneurs, among others, since, in the view of ANFAVEA (2018), it is the primary, indirect productive sectors or services that perform their performance completely affected by the performance of the automobile industry.

It is also possible to highlight another indirect agent: the government, which, by understanding the demand for automobiles, can make predictions of its tax revenues from the entire automobile chain or subsidies to encourage the growth of the sector. According to data from ANFAVEA (2018), the automobile sector generates $R \$ 40$ 
billion in direct tax collection on automobiles per year.

The segmentation of vehicles by cylinder capacity was designed to try to measure the model's accuracy. The choice for the niche between 1000 and 2000 cylinders occurred because, as data from ANFAVEA (2018) point out, it is the niche/segment of cylinders that has greater participation in the volume of total plates in the period covered by the present study (61.7\% between 2012 and 2017).

To understand the main determinants in the demand for automobiles in Brazil, to achieve the objectives initially proposed and to build a model for forecasting automobile demand for a better allocation of economic resources, this research was structured in five sections, in addition to this introduction. In this context, the second section seeks to understand an analysis of the sector, initially addressing a historical context that seeks to investigate which economic policies were adopted by the State to develop the sector. Then, it approaches the sector from the perspective of today, investigating production volumes, sales, imports, exports, market concentration, and industry trends. The third section contemplates the theoretical framework on the theme. The purpose of this section is to find valid bases and methodologies for the construction of the empirical tests proposed in the objectives. The fourth section will present the methodology and variables selected for the formulation of the models, as well as the statistical transformations necessary for the model's validity. The fifth section will cover the main results found. Finally, in the sixth section, the final considerations of the study will be presented.

\section{Development and Current Situation of the Automotive Sector: A Historical Analysis}

As the records of Anfavea (2018) point out, the first motor vehicle arrived in Brazil in 1898. However, the car trade began to develop only in the middle of 1910. Ford started its production in 1925 and General Motors inaugurated its first plant in 1930.

According to Giambiagi et al. (2016), Getúlio Vargas founded CSN and Vale in the 1940s. These companies were key points in the development of the automobile industry concerning the supply of raw materials for the growth of production. Later, Giambiagi et al. (2016) mentions that the postwar international illiquidity had been deteriorating Brazilian external accounts. Thus, the Brazilian government opted for the system of granting licenses for imports, which was a measure that stimulated the national auto industry, since the import of vehicles was restricted by applied protectionism.

Gremaud, Vasconcellos, and Toneto Júnior (2002) emphasize that the 1950s could be considered the culmination of the development of the Brazilian industry. Vargas returns to power and founds Petrobras and BNDE. Oil and credit were seen as fundamental to Brazilian industrial growth. Incentives for the domestic industry were further intensified with SUMOC Instruction 70, which implemented the system of multiple exchange rates, facilitating the import of technologies and other inputs that Brazil did not yet have while preventing the importation of rival goods those produced domestically.

In the view of Gremaud, Vasconcellos, and Toneto Júnior (2002), the economic growth arising from the protectionism of imports was further mitigated with the Goals Plan by Juscelino Kubitscheck. The authors also describe that the plan consisted of direct state investments in the energy and road transport sectors, stimulating the production of intermediate goods that served as industrial inputs (ores) and finally, stimulating the production and consumption of durable goods, with emphasis on automobiles. As a result of these measures, the growth in vehicle production between 1957 and 1961 was higher than 720\%.

Another milestone that completely affected the dynamism of the automobile sector was the commercial opening promoted by Collor, as an attempt to fight inflation. Gremaud, Vasconcellos, and Toneto Júnior (2002) state that there was a reduction in import tariffs, an end to export incentives associated with exchange rate fluctuation. In this way, exports were harmed and imports were benefited, which made imported vehicles gain a greater share within the national market.

Investigating the sector in a modern light, between 2012 and 2017, an average annual production of 2.7 million light vehicles per year was observed in Brazil, which reached a production of 3.4 million in 2013. The auto industry experienced a sharp slowdown in 2014 (-15\%), $2015(-22 \%)$ and $2016(-11 \%)$ with a recovery beginning in $2017(+25 \%)$.

While national production showed a recessive behavior in the period, the number of exported vehicles increased, from $13 \%$ of national production in 2012 to $28 \%$ in 2017 - which indicates that the foreign sector was an important pillar of support for the auto industry. A reverse scenario is perceived when imports are analyzed: in 2012, 27\% of the cars registered in Brazil were imported, while in 2017 the percentage of imported within the demand was $13 \%$. It is also worth noting that the demand for domestic vehicles dropped $32 \%$ in the period, and imported vehicles had their demand reduced by $69 \%$. 
Pindyck and Rubinfeld (2002) express that, in markets that have an oligopolistic structure, the products offered by players may or may not have a difference. However, what is most important in characterizing this type of market is that few companies are responsible for the entire market (or part of it) and this market must present major barriers to entry. Mansfield and Yohe (2006) present the oligopolistic sector or the North American automobile sector as an example, since few companies, such as General Motors, Ford, Toyota, Nissan, and Honda, dominate the sector. In Pindyck and Rubinfeld (2002) it is also used, as an example, in the North American automobile scene. Gremaud et al. (2014) argues that a crucial issue in oligopoly markets is the ability of firms to fix their selling prices, as this resource can generate high prices and, consequently, lower than permitted social consumption, lack of stimulus for new investments in search of testing and lack of improvements, quality and technological advances in products.

Kupfer and Hasenclever (2002), clarify that the capacity of control firms and their selling prices can be called "market power" and claim that industrial concentration measures they use to measure or measure the market power of companies. However, such measures are still incomplete, as they are not considered barriers to the entry of new players, production efficiency, product quality, and the threat of substitute products. One indicator, highlighted by Kupfer and Hasenclever (2002), is an Order Concentration Ratio k, which aims to capture or market power from the largest firms in the industry in question, and helps in the interpretation of the index, states that the higher index value, greater market power measured for the largest companies in the industry.

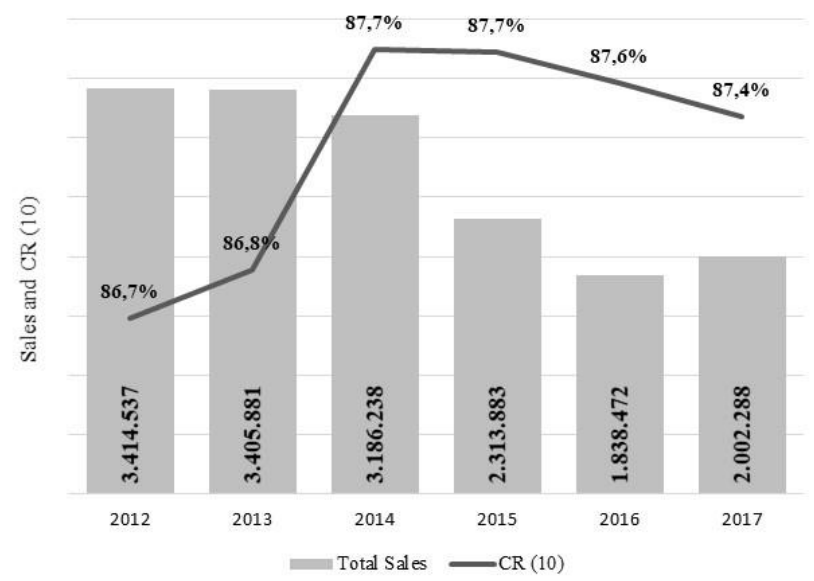

Figure 1. CR (10) of the Brazilian Automobile industry between 2012 and 2017

Figure 1 shows the results achieved when applying the calculation of the Concentration Ratio of Order $k=10$, defended by Kupfer and Hasenclever (2002). Initially, it is observed that there was a decrease in the volume of automakers by $41 \%$ between 2012 and 2017. There is already a curved line under the elucidated graph or the calculated CR (10): a reading of being performed is the one that has a high rate market and, nevertheless, there is no sales volume, the concentration levels intensify.

\section{Determinants of Automobile Demand}

Baumgarten (1972), carried out a study to understand the demand behavior of the Brazilian automobile industry using quarterly information between the years 1960 and 1967 and annual information between 1947 and 1967. The author found, in the research, price elasticity of - 1.91 and income elasticity of 6.28.

In the Milone model (1973 cited by Coates, 1985, p.66) the demand for new cars can be explained by the real gross domestic product with an elasticity coefficient of 2.66 and by a car price index in real terms with a coefficient of -0.55 .

Coates (1985) prepared a study to understand how credit control policies impacted the demand for automobiles in Brazil between the years 1972 and 1981. Among the author's models that have a greater explanatory capacity for the demand for automobiles (75\%), income stands out, with an elasticity of 1.74 , the loan volume of financial companies, with an elasticity of 0.37 , and the loan interest rate, with an elasticity of -1.26 .

Vianna (1988) sought to understand the behavior of the demand for automobiles in Brazil between the years 1976 and 1987. Amid the complexity of the author's model, it is worth highlighting the coefficients of elasticity-income of 0.43 , price-elasticity of -0.55 , elasticity-volume-credit-operations 0.74 . 
Assis (1993) used a model of simultaneous equations to analyze the problems of inflation and the Brazilian balance of payments in the 1970s. One of the equations in the author's model used Brazilian demand for automobiles as a proxy for the private consumption of durable goods. 1970 and 1979. According to the model's results, the income elasticity of demand for automobiles is 1.93 , while the elasticity concerning to interest rates is -0.22 and the elasticity about to the credit availability of the financial system was +0.62 .

In another analysis, De Nigri (1998) estimated the income elasticity and price elasticity of demand for new cars in Brazil using two models: the author's first model has monthly series between 1993 and 1998 and found the main results the price elasticity coefficient of -0.66 and income elasticity of 1.5 . The second model proposed by De Nigri (1998) had as main results the coefficients of income elasticity of 1.11 and price elasticity of -0.57 .

Sanvicente (1998), sought to measure the degree of concentration of the domestic automobile industry between 1990 and 1998. The study showed that for every $1 \mathrm{pp}$ of the price drop, 1,228,195 cars are sold, and when the income evolves $1 \mathrm{pp} 85$ more cars are sold. The study also showed that the relationship between the price of fuel and the demand for automobiles is negative at 1,032,796 when the cost of fuel increases by 1 p.p.

Moraes and Silveira (2004) sought to obtain the value of the elasticity-price and income-elasticity coefficients of demand for popular vehicles in Brazil between 1994 and 2003 and proposed a model that generated the -1.23 elasticity-price coefficients, income elasticity of 0.62 , credit volume-elasticity of 0.66 , interest-elasticity of -0.64 .

Habib (2009) sought to estimate an equation that would represent the demand for automobiles in Brazil between 1999 and 2009 and highlights in his work the coefficients of the dummy variable on the IPI subsidy incidence of 0.46 , of the consumer confidence index of 0,19 , the average financing term of 0.17 and industrial production of 3.68. In his work, the elasticity-price coefficient showed a positive sign $(+0.45)$ and was treated as spurious.

In the empirical tests of DIMAC / IPEA (2009), the estimated income elasticity for automobile demand is 2.55. The price elasticity is -2.84 and the work still considered the credit elasticity of 0.38 . DISET / IPEA (2010), on the other hand, estimates that $20.7 \%$ of car sales in 2009 have been influenced by the IPI subsidies assessed to the sector. The model proposed by DISET / IPEA (2010) resulted in the income elasticity of 4.42, price elasticity of -2.53 , and a credit elasticity of 1.18 .

Poletto (2012), aimed to analyze the behavior of the demand for commercial and light vehicles in the Rio Grande do Sul between 2004 and 2010. The model in question found that for every $1 \mathrm{pp}$ of a drop in IPI rates, 54 thousand new cars were demanded, while the 1 pp drop in interest rates stimulated the consumption of 622 cars. In the survey, unexpected results also occurred: positive price elasticity of 637 vehicles and negative income elasticity in 97 cars - results considered spurious by the author.

Tyng (2016) sought, through the analysis of income-elasticity and price-elasticity, to understand the behavior of the demand for "premium" and "common" segment cars in Brazil between the years 2003 and 2015. Tyng (2016) estimated for the premium segment, income elasticity was 2.14 while for the common segment, 1.78 . In the analysis of the elasticity-activity-economic coefficient for the premium segment, the indicator was 0.43 , while for the common segment it was 2.44 .

Lucinda and Pereira (2017) sought to present the effects propagated under the demand and supply of cars in Brazil, given the reductions in IPI rates. The authors expose a reduction in the IPI as a subsidy to the automobile sector after the Subprime crisis in 2008 and the estimates observe an income elasticity of 2.70 .

In summary with the exposed literature, it is observed that, in general, several authors used variables to measure income elasticity and price elasticity, and that these variables presented the expected behavior, according to economic theory, except for Poletto's works ( 2012) and Habib (2009). In this context, the objective of Table 1 is to summarize the main results found in the literature consulted about the income and price elasticities of demand for automobiles in Brazil.

The table can still be complemented by the work of Sanvicente (1998), who found an increase of 1,228,195 in the quantity demanded of cars for every $1 \mathrm{pp}$ of the drop in prices and an increase of 85 cars for every $1 \mathrm{pp}$ of increase in agents' income economical. Poletto (2012) estimated that a 1 p.p. increase in prices increases the quantity demanded cars by 637 units and that a 1 p.p. increase in agents' income reduces the demand for cars by 97 units. 
Table 1. Consolidation of elasticities

\begin{tabular}{lcc}
\hline Author & Income & Price \\
\hline Assis (1993) & 1,93 & - \\
Baumgarten (1972) & 6,28 & $-1,91$ \\
Coates (1985) & 1,74 & - \\
De Nigri (1998) & 1,50 & $-0,66$ \\
De Nigri (1998) & 1,11 & $-0,57$ \\
Habib (2009) & - & 0,45 \\
DIMAC/IPEA (2009) & 2,55 & $-2,84$ \\
DISET/IPEA (2010) & 4,42 & $-2,53$ \\
Lucinda e Pereira (2017) & 2,70 & - \\
Milone (1973) & 2,66 & $-0,55$ \\
Moraes e Silveira (2004) & 0,62 & $-1,23$ \\
Tyng (2016) & 2,14 & - \\
Tyng (2016) & 1,78 & - \\
Vianna (1988) & 0,43 & $-0,55$ \\
\hline
\end{tabular}

Source: Prepared by the authors.

\section{Methodology}

In this research, an econometric model based on Ordinary Least Squares will be adopted to perform econometric tests, as mentioned above. Initially, a model will be formulated to show the income and price elasticities of the demand for automobiles, and, for this purpose, the monthly series of vehicle license plates between 1000 and 2000 cylinders made available by ANFAVEA will be used as dependent variables. As an explanatory variable, the series of Monthly GDP in Current Values will be used, made available in the Time Series Management System of the Central Bank of Brazil - which will serve as a proxy for consumers' income. As a proxy for vehicle prices, an index built by the authors will be used, which consists of an average price of the 5 best-selling vehicles per month, weighted by the quantities sold (for the construction of such indicator, the numbers of monthly plates consulted in Revista Quatro were used) Wheels and sales prices of the respective vehicles in the FIPE Table for the current period). Finally, to meet the assumptions pointed out by Gujarati and Porter (2011), the variables will be transformed with the application of logarithms (log-log model). The transformation allows the coefficients to be interpreted directly as elasticities. In this context, Figure 2 presents a set of graphs that show the behavior of the three time series used in the model, after going through the necessary transformations.
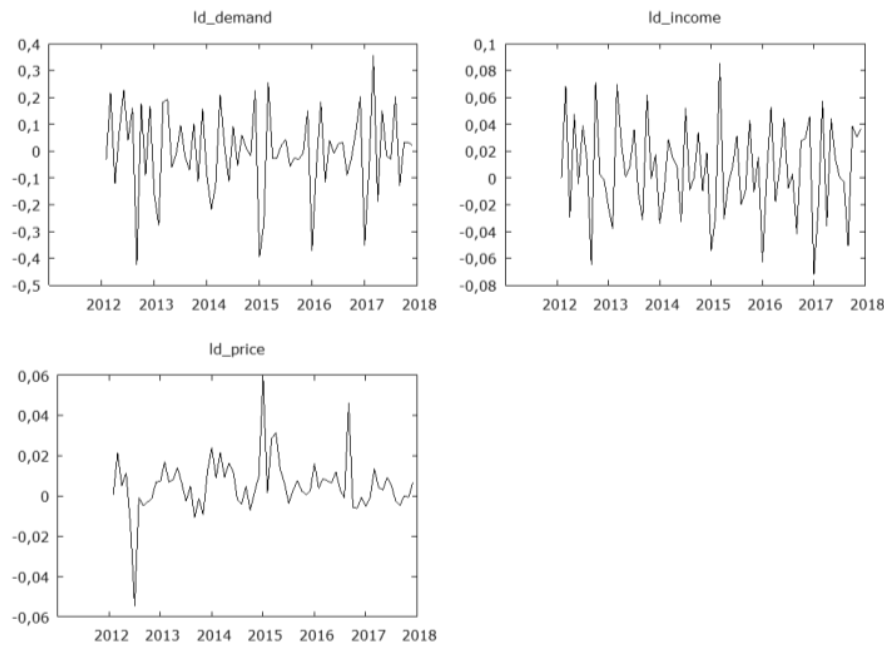

Figure 2. Variables of the first model

Source: ANFAVEA, BCB, Tabela FIPE and Quatro Rodas.

The second model of the present work will aim to measure the impacts of the main determinants of demand for automobiles in Brazil. In addition to the three variables used in the first model, the monthly series CDC - Banks Auto Finance provided by the National Association of Finance, Administration and Accounting Executives (ANEFAC) will be used as a proxy for vehicle financing interest rates. This series is formulated based on a survey by the institution on car financing rates in the national market and is released monthly. 
Based on the theoretical framework, the IPI rates proved to be important determinants in the demand for automobiles and will also be used as explanatory variables. As a complement to the model, there will be two more dummy variables that will assume the value equal to 1 when it is February and December. This is because observing the monthly series of license plates, it is possible to perceive that historically the month of February is the month with the lowest number of license plates of the respective year, whereas in December the highest number of vehicle plates is observed.

It is worth noting that for this model the variables will also transform so that they are statistically valid, as they had a unit root in the increased Dickey and Fuller test. The series that assumes the role of proxy for demand, income, and price, will be regressed in time and their respective residues will be used to compose the second model proposed in this work. According to Gujarati and Porter (2011), series that have a unit root are stationary around the trend line - they also state that regressing the variable with unit root in time (t), the residuals ( $(\hat{\mathrm{u}})$ of the regression will be stationary.

For example:

$$
Y_{i}=\beta_{1}+\beta_{2} \times t+u_{i}
$$

Rearranging the terms of the regression, in the ideas of Gujarati and Porter (2011) the residue û, will be stationary:

$$
\hat{\mathrm{u}}_{i}=\left(Y_{i}-\beta_{1}-\beta_{2} \times t\right)
$$

Finally, the first differences in the variables that will be used as a proxy for the vehicle financing interest rate and the IPI rate will be used. In this way, the unit root problem of the variables mentioned above will be solved. Figure 3 presents a panel with the behavior of the time series that will be used in the model after due statistical changes: logarithm of the residual demand, income, and price; the first differences in financing interest rates and IPI rates.
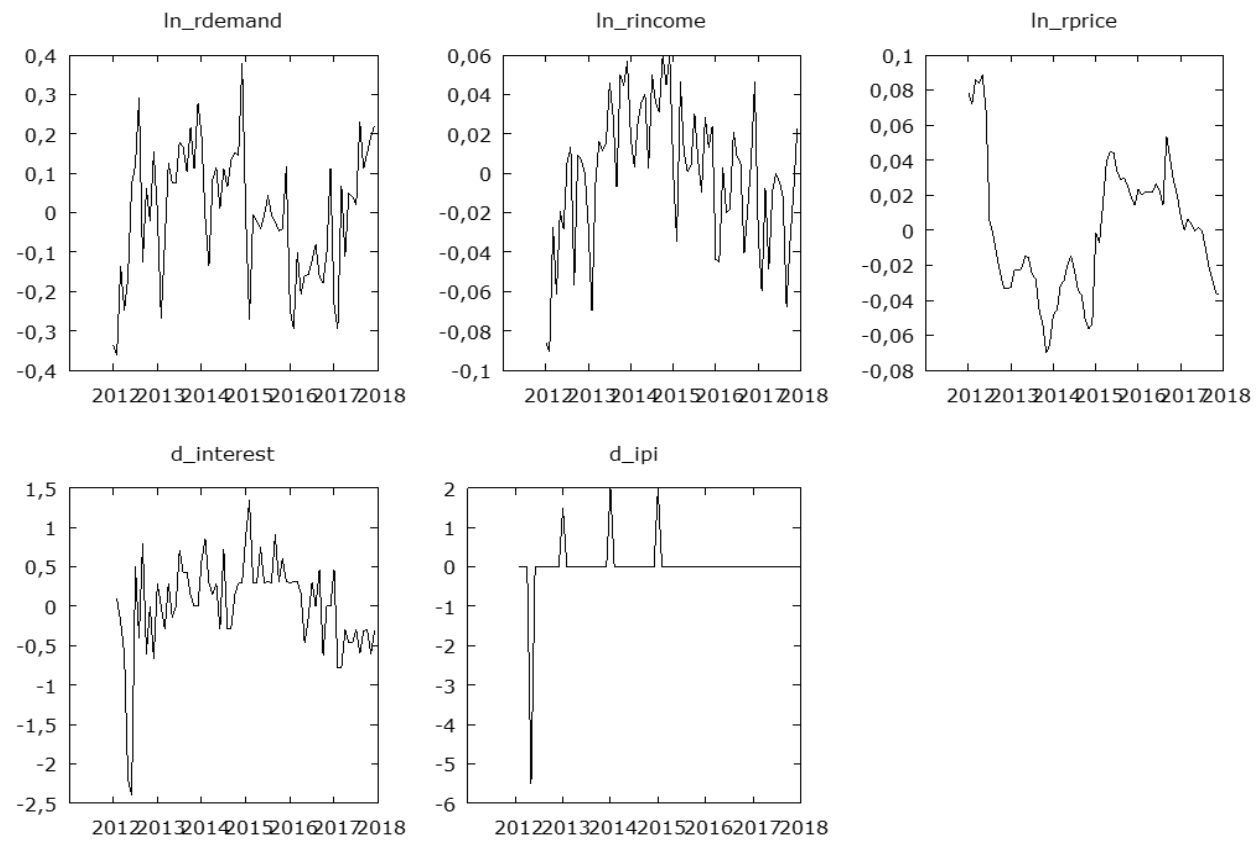

Figure 3. Variables of the second model

Source: ANFAVEA, BCB, Tabela FIPE, Quatro Rodas and ANEFAC.

\section{Results and Discussion}

The first model proposed, to estimate income-elasticity and price-elasticity, can be described as follows:

$$
\text { d_demand }=\beta_{1}+\beta_{2} \text { ld_income }-\beta_{3} l d \_ \text {price }
$$

Table 2 shows the results obtained in the regression. 
Table 2. Estimated income and price elasticity

\begin{tabular}{lccccc}
\hline $\begin{array}{l}\text { Dependent Variable: } \text { ld_demand } \\
\text { Explanatory Variables: }\end{array}$ & coef. & std. error & t-student & p-value & FIV \\
\hline const & $-0,015$ & 0,013 & $-1,112$ & 0,270 \\
ld_income & 3,418 & 0,346 & 9,888 & 0,000 & 1,025 \\
ld_price (1) & $-1,537$ & 0,877 & $-1,754$ & 0,084 & 1,025 \\
Adjusted $\boldsymbol{R}^{2}$ & 0,608 & $\boldsymbol{R E S E T}$ test & 0,001 & White test & 0,909 \\
$\boldsymbol{F}$ test & 0,000 & Breusch-Godfrey test & 0,051 & Jarque-Bera test & 0,348 \\
\hline
\end{tabular}

Source: Prepared by the authors.

This model has an explanatory power of the dependent variable of $61 \%$ (adjusted R-squared) and is, as a whole, statistically significant according to the $\mathrm{F}$ of significance. The model shows an income elasticity of 3.42 (significant with $99 \%$ confidence) and price elasticity of -1.54 (significant with $90 \%$ confidence). With the application of the White Test, it was possible to reject the hypothesis of heteroscedasticity and not to reject the hypothesis of homoscedasticity. The model does not present the multicollinearity problem since the Variance Inflation Factors test showed results of 1.03 for both variables. However, problems were found in calculating the RESET test, in which the probability of the model being correctly specified is $0.124 \%$ and in the LM test, which claims that the probability of absence of autocorrelation is $5.06 \%$.

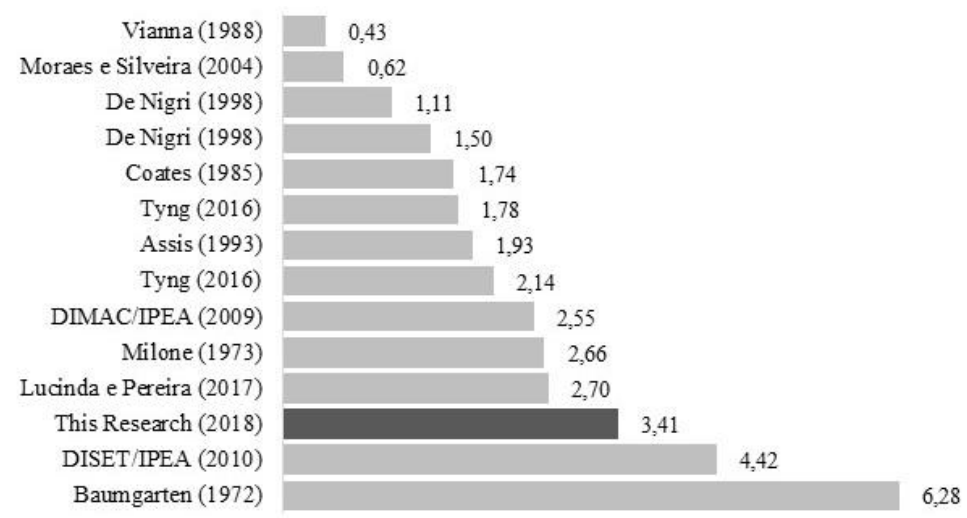

Figure 4. Estimated income elasticity

Figure 4 shows better the results obtained on income elasticity. It can be seen that the estimated beta of 3.41 is in line with the consulted theoretical framework. The estimated result is also in line with what was presented by Pindyck and Rubinfeld (2002) when addressing the concept of "cyclical industry". The conclusion, demonstrated by the authors, is that the automobile industry has a direct relationship with the growth trends of the industry: with each $1 \%$ increase in agents' income, the demand for automobiles increases by $3.41 \%$.

Thus, the demand for automobiles can be characterized as elastic concerning to income from the perspective of the magnitude of the estimated beta-income and as a normal / higher good, according to the concepts of Mansfield and Yohe (2006), due to the positive sign of the coefficient.

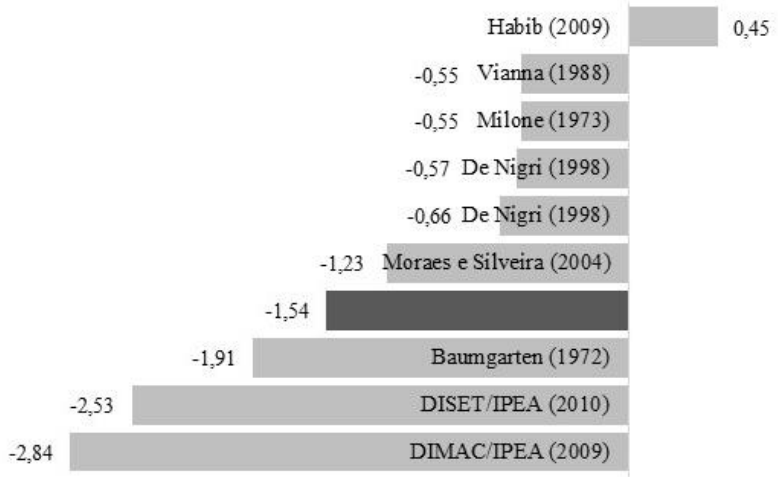

Figure 5. Estimated price elasticity 
Figure 5, on the other hand, elucidates the behavior measured for price elasticity, which was also following the economic theory proposed by Mansfield and Yohe (2006). It can be interpreted that for each $1 \%$ increase in prices, the demand for automobiles tends to decrease by $1.54 \%$ in the subsequent period (since there is a lag of 1 period in the estimate) - characterizing it as an elastic good about to the price. The beta-income signal is in line with the consulted theoretical framework, except for the work of Habib (2009), in which the author points out that his estimation can be considered spurious because it presents a sign contrary to what the economic theory predicts. Regarding the magnitude of the beta-income, the estimated result in the present work is in line with the works of Moraes and Silveira (2004), Baumgarten (1972), DISET / IPEA (2010) and DIMAC / IPEA (2009), in that the estimated results suggest that demand has an elastic characteristic to sales prices. At the end of the first stage, there is now a new model that aims to measure the impacts of the main determinants on the demand for cars, shown in Table 3.

Table 3. Determinants of demand for automobiles in Brazil

\begin{tabular}{lccccc}
\hline $\begin{array}{l}\text { Dependent Variable: } \text { In_rdemand } \\
\text { Explanatory Variables: }\end{array}$ & coef. & std. error & $\boldsymbol{t}$-student & $\boldsymbol{p}$-value & $\boldsymbol{F I V}$ \\
\hline const & 0,009 & 0,012 & 0,807 & 0,423 & \\
In_rincome & 1,765 & 0,417 & 4,230 & 0,000 & 1,633 \\
ln_rprice (1) & $-2,070$ & 0,353 & $-5,860$ & 0,000 & 1,452 \\
d_interest & $-0,061$ & 0,019 & $-3,152$ & 0,003 & 1,227 \\
d_ipi (2) & $-0,060$ & 0,014 & $-4,139$ & 0,000 & 1,112 \\
february & $-0,165$ & 0,046 & $-3,544$ & 0,001 & 1,310 \\
december & 0,084 & 0,040 & 2,114 & 0,039 & 1,144 \\
Adjusted $\boldsymbol{R}^{\mathbf{2}}$ & 0,679 & RESET test & 0,626 & White test & 0,761 \\
F test & 0,000 & Breusch-Godfrey test & 0,149 & Jarque-Bera test & 0,144 \\
\hline
\end{tabular}

In the proposed new model for determining the demand for automobiles in Brazil, all variables are significant at the $95 \%$ confidence level. The signs of the estimated betas are by the consulted theory and the model does not present multicollinearity problems.

It should be noted that the model, which is a significant whole, has an explanatory power of $68 \%$ of the dependent variable. The model has a p-value of 0.76 for the heteroscedasticity test and 0.63 for the specification test. About the magnitude of the betas, it is understood that the month of February has a negative impact of greater expression than the month of December, positively. Unlike the model in which we aim to estimate income-elasticity and price-elasticity, in this case prices had a greater impact on the demand for automobiles than income. Finally, the demand for automobiles proved to be more sensitive to movements in the IPI rate than to changes in average auto finance interest in Brazil.

\section{Final Considerations}

The present work aimed to analyze the demand for automobiles in Brazil. Additionally, the research contemplated secondary objectives that were fulfilled and analyzed. Initially, we sought to understand how the sector developed and, for that, it was observed that the description of the sector's development can be based on two distinct fronts: the first, guided by the State, which acted directly and indirectly in the economy with investments massive infrastructure, creation of state-owned companies to supply inputs for the production of vehicles and protectionism vis-à-vis the foreign market with higher taxes on imported products and exchange devaluations. Such public measures have accelerated the volume of production, expansion of the level of employment, growth of the entire production chain, and expansion of government revenue, configuring the sector as one of the main drivers of Brazilian historical growth.

Then, the aim was to estimate the income elasticity of demand for cars in Brazil. The results found to indicate the income elasticity of demand of 3.41. The data found are statistically valid and are in line with the theoretical framework addressed. This market confirms the characteristic of a cyclical industry, with elastic demand with income and goods classified as normal / higher.

Subsequently, an attempt was made to estimate the price elasticity of demand for automobiles, and the tests applied indicated an elasticity of $|-1.54|$, since it is also statistically valid and is in line with the consulted theoretical framework. This confirmed the expected characteristic that this market offers elastic goods concerning prices. 
Finally, it was expected to develop a model capable of describing the demand for cars with the additional purpose of making demand forecasts. In section 5, the proposed final model that uses income, price, financing interest rates, IPI rate and seasonality of February and December to explain the demand for automobiles proved to be satisfactory to represent the demand for automobiles, since it presented $68 \%$ explanatory power over demand. The same model, when compared with historical data, also proved to be valid for making predictions. It should be noted that, even with the advent of several variables, income and price are still the elements with the most significant impacts on demand. Additionally, it is worth noting that the price variable needs two lags to have significant effects.

The cost of credit for financing presented the estimated beta with less magnitude, which may indicate that, on average, Brazilians are not bothered by the high interest rates for financing new vehicles. Still linked to this topic and which may open space for new discussions are the possible impacts of the high degree of default on the Brazilian economy and the banking concentration in the financial system that can raise the cost of credit.

The hypothesis raised to interpret the beta of February's seasonality is that it is the month with the fewest days of the year and that, combined with the typical and cultural festivities of Brazil, reduce the number of sales. However, it would be necessary to ascertain the average daily sales for February compared to other months to corroborate this hypothesis.

About the December seasonality beta, the hypothesis for interpretation is that it is the period in which Brazilians generally receive additional salaries, bonuses, premiums, and benefits from their jobs. Therefore, it is the period when consumers have the highest disposable income to consume.

Regarding the IPI rates, we have reached the expected expectations, even considering the use of two time lags, which indicates that it takes some time for the taxation changed by the government to have an impact on the real side of the economy affecting demand. It was also raised in this research that the market has the oligopolistic characteristic of production since it has a high degree of industrial concentration (the 10 largest players have a market share of more than $80 \%$ ), which can be harmful to consumers and suppliers by the high bargaining power of the current economic agents that make up the market.

\section{Acknowledgments}

This work has been supported by grants from the Mackenzie Research Fund (MackPesquisa).

\section{References}

ANFAVEA - Associação Nacional dos Fabricantes de Veículos Automotores. (2018, January 07). Retrieved from http://www.anfavea.com.br/index.html

ANFAVEA - Associação Nacional dos Fabricantes de Veículos Automotores. (2018, March 31). Retrieved from http://www.anfavea.com.br/docs/25.04.17_PressRelease_Setor\%20automotivo\%20apresenta\%20ao\%20Go verno\%20os\%20pilares\%20para\%20a\%20constru\%C3\%A7\%C3\%A3o\%20da\%20ind\%C3\%BAstria\%20d o\%20futuro\%20at\%C3\%A9\%202030.pdf>

Assis, M. (1983, October). A estrutura e o mecanismo de transmissão de um modelo macroeconométrico para o Brasil (MEB). Revista Brasileira de Economia, 37(4), 483-512. Retrieved from http://bibliotecadigital.fgv.br/ojs/index.php/rbe/article/download/314/7721

BACEN - Banco Central do Brasil. (2018, March 15). Retrieved from https://www3.bcb.gov.br/sgspub/consultarvalores/consultarValor esSeries.do?method=consultarValores

Baumgarten Jr., A. L. (1972, June). Demanda de automóveis no Brasil. Revista Brasileira de Economia, 26(2), 203-297. Retrieved from http://bibliotecadigital.fgv.br/ojs/index.php/rbe/article/viewFile/76/2901

Coates, M. V. (1985). Política de crédito ao consumidor e desempenho do setor industrial: uma análise da experiência brasileira, 1972-1981. (Master's thesis, Pontífica Universidade Católia, Rio de Janeiro, Brazil). Retrieved from http://www.econ.puc-rio.br/biblioteca.php/trabalhos/show/745/en

De Nigri, J. A. (1998). Elasticidade-Renda e Elasticidade-Preço da Demanda de Automóveis no Brasil. Texts for $\begin{array}{lllll}\text { Discussion } & - & \text { IPEA, } & 558 . & \text { Retrieved }\end{array}$ https://www.ipea.gov.br/agencia/images/stories/PDFs/TDs/td_0558.pdf

FGV - Fundação Getúlio Vargas. (2018, April 30). Retrieved from http://portalibre.fgv.br/main.jsp?lumChannelId=402880811D8E 34B9011D92BA032B198D>

FIPE - Fundação Instituto de Pesquisa Econômica. (2018, March 23). Retrieved from http://veiculos.fipe.org.br/ Giambiagi, F. et al. (2016). Economia Brasileira Contemporânea: 1945-2015 (3rd ed.). Rio de Janeiro: Elsevier. 
Gremaud, A. P. et al. (2014). Manual de Economia: Equipe de professores da USP (5th ed.). São Paulo: Saraiva.

Gremaud, A. P., \& Vasconcellos, M. A. S., \& Junior, R. T. (2002). Economia Brasileira Contemporânea (4th ed.) São Paulo: Atlas.

Gujarati, D. N., \& Porter, D. C. (2011). Econometria Básica (5th ed). Porto Alegre: Mc Graw.

HABIB, N. (2009). Determinantes da demanda de automóveis no Brasil. Graduation Monograph, INSPER, São Paulo, Brazil.

IBGE - Instituto Brasileiro de Geografia e Estatística. (2018, January 21). Retrieved from https://ww2.ibge.gov.br/home/estatistica/indicadores/precos/i npc_ipca/defaultinpc.shtm

IPEA - Instituto de Pesquisa Econômica Aplicada. (2009). Impactos da Redução do Imposto sobre Produtos Industrializados (IPI) de automóveis. Nota Técnica. Brasília: IPEA/DIMAC, n. 15. aug. 2009. Retrieved from http://repositorio.ipea.gov.br/bitstream/11058/5800/1/NT_n15_Impactos-reducao-imposto_Dimac_ 2009-ago.pdf

IPEA - Instituto de Pesquisa Econômica Aplicada. (2010). Políticas Anticíclicas na Indústria Automobilística: Uma Análise de Cointegração dos Impactos da Redução do IPI Sobre as Vendas de Veículos. Texts for Discussion. Rio de Janeiro: IPEA/DISET, n. 1512, 9-21 p. oct. 2010. Retrieved from http://repositorio.ipea.gov.br/bitstream/11058/1372/1/TD_1512.pdf

Kupfer, D., \& Hasenclever, L. (2002). Economia Industrial: Fundamentos Teóricos e Práticas no Brasil (9th ed.). Rio de Janeiro: Elsevier.

Lucinda, C. R., \& Pereira, L. M. S. (2017). Efeitos da política de Redução do IPI sobre o mercado de automóveis novos. Scientific Work - Public Sector Economics -ANPEC Retrieved from https://www.anpec.org.br/encontro/2017/submissao/files_I/i5-b800b127b8fe1398f5d2a206f9f9c785.pdf

Mansfield, E., \& Yohe, G. (2006). Microeconomia (11th ed.) São Paulo: Saraiva.

Milone, P. C. (1992). A demanda de automóveis no Brasil: 1961-1969. São Paulo, IPE-USP.

Moraes, R. A., \& Silveira, S. A. G. D. (2004). Elasticidade-Preço E Elasticidade-Renda Da Demanda Na Indústria Automobilística Brasileira: Uma Análise Da Última Década Para Os Veículos Populares. Trabalho Científico-Política Dos Negócios E Economia De Empresas. EAD-FEA USP. Retrieved from https://www.academia.edu/6633924/ELASTICIDADE_-_PRE\%C3\%870_E_ELASTICIDADE_-_RENDA _DA_DEMANDA_NA_IND\%C3\%9ASTRIA_AUTOMOBIL\%C3\%8DSTICA_BRASILEIRA_UMA_AN \%C3\%81LISE_DA_\%C3\%9ALTIMA_D\%C3\%89CADA_PARA_OS_VE\%C3\%8DCULOS_POPULARE $\mathrm{S}$

Pindyck, S. R., \& Rubinfeld, D. L. Microeconomia (5th ed.). São Paulo: Prentice Hall.

Poletto, L. F. (2012). Análise da demanda por automóveis e comercias leves novos no Rio Grande do Sul no período de 2004 a 2010. Graduation Monograph, College of Horizontina, Horizontina, Brazil.

Quatro Rodas. (2018, March 23). Retrieved from https://quatrorodas.abril.com.br/top-50-2016/

Sanvicente, A. Z. (1998). Competição na Indústria automobilística Brasileira (Unpublished Article).

Tyng, C. T. (2016). Uma análise dos grupos premium e comum do setor automobilístico Brasileiro (Janeiro/2003 - Julho/2015). Graduation Monograph, INSPER São Paulo, Brazil.

Vianna, R. L. L. (1988). O comportamento da demanda de automóveis: Um estudo econométrico. (Master's thesis, Pontifícia Universidade Católica, Rio de Janeiro, Brazil) Retrieved from http://www.econ.puc-rio.br/biblioteca.php/trabalhos/show/771

\section{Copyrights}

Copyright for this article is retained by the author(s), with first publication rights granted to the journal.

This is an open-access article distributed under the terms and conditions of the Creative Commons Attribution license (http://creativecommons.org/licenses/by/4.0/). 